\title{
The impact of selected cardiovascular factors on the safety and efficacy of intravenous thrombolysis for acute ischemic stroke in routine practice in a rural hospital
}

\author{
Wpływ wybranych czynników sercowo-naczyniowych na bezpieczeństwo \\ i skuteczność dożylnego leczenia trombolitycznego u chorych z niedokrwiennym \\ udarem mózgu w codziennej praktyce w szpitalu $w$ rejonie wiejskim
}

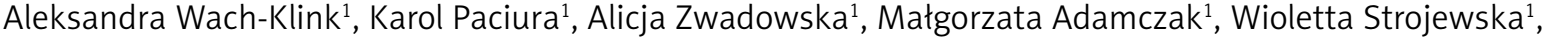 \\ Tadeusz Frańczak-Prochowski²
}

'Department of Neurology and Stroke Unit of Holy Spirit Specialist Hospital, Sandomierz, Poland Head of the Department: Prof. JKU Piotr Sobolewski MD, PhD

2Laboratory Diagnostics, Holy Spirit Specialist Hospital, Sandomierz, Poland

Head of the Laboratory: Anna Dobrowolska-Hemine MA

Medical Studies/Studia Medyczne 2018; 34 (3): 232-240 DOI: https://doi.org/10.5114/ms.2018.78687

Key words: cardiovascular factors, echocardiography findings, ischemic stroke, rt-PA, intravenous thrombolysis.

Słowa kluczowe: czynniki sercowo-naczyniowe, znaleziska echokardiografii, udar niedokrwienny mózgu, rt-PA, dożylna tromboliza.

\begin{abstract}
Introduction: Cardiac and electrocardiography (ECG) abnormalities are common in acute ischemic stroke (AIS) patients. Aim of the research: To evaluate the relationship between selected cardiovascular factors and the long-term outcome, the presence of hemorrhagic transformation (HT), symptomatic intracerebral hemorrhage (SICH) and mortality in Caucasian patients with AIS treated with intravenous thrombolysis (i.v. thrombolysis) in routine practice.

Material and methods: We prospectively evaluated 286 stroke patients in terms of the impact of cardiovascular factors and changes in the transthoracic echocardiogram (TTE) on the safety and effectiveness of intravenous (i.v.) thrombolysis.

Results: In the analyzed group we found atrial fibrillation (AF) in 35.3\% of patients and cardiogenic stroke in 31.5\% of patients. The first abnormal ECG $(p=0.02)$ and the presence of AF ( $p=0.002)$ were higher in patients with an unfavorable outcome (modified Rankin Scale, 3-6 points) and in patients who died within 3 months' follow-up ( $p=0.02, p=0.004$ respectively). Only median NIHSS score at the time of admission was associated with cardiogenic stroke $(p=0.01)$. There was no impact of TTE findings on safety and efficacy of i.v. thrombolysis. No significant differences in the long-term outcome, HT and SICH rates and mortality between the subgroups of patients with cardiogenic stroke and patients with other types of strokes were observed. Multivariate analysis showed the impact of AF on the long-term unfavorable outcome $(p=0.02)$ and mortality rate $(p=0.04)$.

Conclusions: Atrial fibrillation is a strong predictor of unfavorable long-term outcome and death in patients with AIS treated with i.v. thrombolysis in routine practice. Further studies assessing cardiac function in patients undergoing i.v. thrombolysis are needed.
\end{abstract}

\section{Streszczenie}

Wprowadzenie: Nieprawidłowości w badaniu kardiologicznym i elektrokardiograficznym (EKG) często występują u pacjentów z ostrym udarem niedokrwiennym mózgu (AIS).

Cel pracy: Ocena zależności między wybranymi czynnikami sercowo-naczyniowymi a odległym wynikiem leczenia, obecnością zmian krwotocznych (HT), objawowych krwotoków śródmózgowych (SICH) i umieralnością pacjentów rasy kaukaskiej z AIS leczonych trombolizą dożylną (i.v.) w rutynowej praktyce klinicznej.

Materiał i metody: Prospektywnie oceniano dane 286 pacjentów pod względem wpływu czynników sercowo-naczyniowych i zmian w echokardiografii przezklatkowej (TTE) na bezpieczeństwo i skuteczność trombolizy i.v.

Wyniki: W analizowanej grupie migotanie przedsionków (AF) występowało u 35,3\%, a udar kardiogenny u 31,5\% pacjentów. Nieprawidłowy pierwszy zapis EKG $(p=0,02)$ i obecność AF $(p=0,002)$ częściej stwierdzano u pacjentów z niekorzystnym wynikiem leczenia (zmodyfikowana skala Rankina, mRS 3-6 pkt) oraz u pacjentów, którzy zmarli w ciągu 3 miesięcy obserwacji (odpowiednio $p=0,02, p=0,004$ ). Jedynie mediana skali NIHSS w momencie przyjęcia była związana z udarem kardiogennym $(p=0,01)$. Nie zaobserwowano istotnych różnic w odległym wyniku leczenia, częstości występowania SICH 
oraz śmiertelności między podgrupami pacjentów z udarem kardiogennym i udarami o innej etiologii. Analiza wieloczynnikowa wykazała wpływ AF na długoterminowy niekorzystny wynik leczenia $(p=0,02)$ i śmiertelność $(p=0,04)$.

Wnioski: Migotanie przedsionków jest silnym predyktorem niekorzystnego odległego wyniku leczenia oraz zgonu u pacjentów z AIS leczonych za pomocą trombolizy i.v. w rutynowej praktyce lekarskiej. Konieczne są dalsze badania oceniające funkcję serca u pacjentów z udarem poddawanych trombolizie i.v.

\section{Introduction}

The co-occurrence of heart and cerebrovascular diseases is very common. This is related to common risk factors and in many cases similar etiopathogenesis and therapeutic decisions that are mutually dependent on each other. According to previous studies, cardiogenic etiology occurs in $22-39 \%$ of ischemic strokes [1]. Studies using prolonged cardiac monitoring indicate higher incidence of serious arrhythmias, which leads to the conclusion that cardiogenic stroke occurs in a greater proportion.

Cardiac and electrocardiogram (ECG) abnormalities are common in acute stroke patients, especially if the insular cortex is involved [2, 3]. Cardiac dysfunction in stroke patients may be particularly damaging. Within the territory of tissue affected by an acute ischemic stroke (AIS) intrinsic autoregulation of the vasculature is lost, rendering cerebral blood flow directly dependent only on cardiac function [4]. An admission ECG, cardiac biomarkers and cardiovascular monitoring should be conducted routinely after an acute cerebrovascular event to screen for serious cardiac arrhythmias [5]. Holter monitoring is superior to routine ECG for the detection of atrial fibrillation (AF) in patients anticipated to have thromboembolic stroke [6] Transthoracic echocardiography (TTE) and especially transesophageal echocardiography (TEE) can detect a potential cardiac source of embolism $[7,8]$.

Systemic thrombolysis (i.v. thrombolysis) with recombinant tissue plasminogen activator (rt-PA), initiated within $4.5 \mathrm{~h}$ of the onset of symptoms, is an effective medical therapy for acute ischemic stroke, but is associated with a number of hemorrhagic complications and is contraindicated in patients with severe hemostatic disorders [5, 9].

\section{Aim of the research}

Our study aimed to evaluate the relationship between selected cardiovascular factors, TTE and TEE findings and the long-term functional outcome, the presence of hemorrhagic complications and mortality in Caucasian patients with AIS treated with i.v. thrombolysis in routine practice.

\section{Material and methods}

\section{Study design and patients}

We prospectively evaluated the clinical and epidemiological data of 286 Caucasian patients with AIS who were consecutively treated with i.v. thrombolysis from January 2008 to December 2012 in the De- partment of Neurology and Stroke Unit of the Holy Spirit Specialist Hospital in Sandomierz. Our study center was recognized as a stroke unit according to the Polish national criteria and was equipped with the proper monitoring and diagnostic facilities [10]. Our unit provided a 24-h stroke service 7 days a week. All patients were examined at the time of admission by a stroke physician, and the severity of stroke symptoms was assessed using the National Institutes of Health Stroke Scale (NIHSS) [11]. Stroke was diagnosed on the basis of the ICD 10 criteria and was confirmed on discharge by clinical evaluation and using neuroimaging findings. All biochemical samples were routinely taken at the time of admission and the results of biochemical analyses were obtained before starting i.v. thrombolysis. Computed tomography (CT) scans were performed in all patients upon admission to hospital and between 22 and $36 \mathrm{~h}$ after i.v. thrombolysis. In selected cases, especially in case of hemorrhagic complications, additional CT scans were performed according to the patient's status and clinical indications. Magnetic resonance imaging (MRI) was not routinely performed.

Clinical cardiovascular evaluation was performed through a general physical examination, ECG on admission, 3-day monitoring of heart rate and blood pressure, the Holter-ECG test, chest X-ray and TTE and in selected cases TEE performed according to the current echocardiography guidelines and standards [12]. Assessment of cardiovascular risk factors was also performed. In the evaluation of congestive heart failure $(\mathrm{CHF})$ the following variables were registered: history of heart failure, New York Heart Association functional classification (NYHA) dichotomized as $<$ stage II and $\geq$ stage II, left ventricular ejection fraction (dichotomized as $\leq 44 \%$ and $>44 \%$, left atrium diameter (dichotomized as $\leq 38 \mathrm{~mm}$ and $>38 \mathrm{~mm}$ for women and $\leq 46 \mathrm{~mm}$ and $>46 \mathrm{~mm}$ for men) and end-diastolic left ventricular diameter (dichotomized as $\leq 57 \mathrm{~mm}$ and $>57 \mathrm{~mm}$ for women and $\leq 63 \mathrm{~mm}$ and $>63 \mathrm{~mm}$ for men). The adopted values of TTE corresponded to moderately and severely abnormal (in accordance with the American Society of Echocardiography Guidelines and Standards) [12].

Cases related to AF, valvular disease, congestive heart failure, patent foramen ovale and aortic embolism were defined as cardiogenic stroke.

Cerebral thrombolysis with the intravenous infusion of rt-PA was administered according to the current guidelines $[5,12]$. Patients treated $>4.5 \mathrm{~h}$ from the stroke onset and patients treated with combina- 
tion therapy (intravenous and intraarterial thrombolysis) were excluded from the study.

The 90-day stroke outcomes were measured with the modified Rankin scale (mRS) [13]. A favorable outcome was defined as an mRS score $\leq 2$ points, while an unfavorable outcome was defined as an $\mathrm{mRS}$ of 3-6 points. Hemorrhagic transformation (HT) and symptomatic intracerebral hemorrhage $(\mathrm{SICH})$ rates were assessed according to the European Cooperative Acute Stroke Study (ECASS) II criteria [14].

The ethics committee approved all data analyses.

\section{Statistical analysis}

This study was based on a prospective data analysis. A statistical analysis was performed with Statistica v. 9.1 All continuous variables were tested for normal distribution and equality of variance. Because of the non-normality of the variables, the non-parametric Mann-Whitney $U$ test was used to perform the uni- variate analysis of the continuous variables. Categorical data were compared using the $\chi^{2}$ test. The multivariate analysis was performed using multiple logistic regression. For logistic regression those variables which showed discrimination power $p<0.1$ in univariate analysis were selected. The results of the logistic regression models were presented as odds ratios (ORs) and the corresponding 95\% confidence intervals (CIs). $P$-values $<0.05$ were considered statistically significant.

\section{Results}

In the analyzed group a favorable outcome was found in $56.6 \%$ of patients and an unfavorable outcome was identified in $43.4 \%$ of patients; $17.8 \%$ of patients died within 90 days of the stroke onset. The HT was found in $15.7 \%$ of patients, and $\mathrm{SICH}$ was found in $4.2 \%$ of patients. We found $\mathrm{AF}$ in $35.3 \%$ and con-

Table 1. Clinical characteristics of subgroups of stroke patients with a favorable and an unfavorable outcome after i.v. thrombolysis

\begin{tabular}{|c|c|c|c|}
\hline Variables & $\begin{array}{c}\text { Favorable outcome } \\
\text { (mRS 0-2) } \\
n(\%)\end{array}$ & $\begin{array}{c}\text { Unfavorable outcome } \\
\text { (mRS 3-6) } \\
n(\%)\end{array}$ & $P$-value \\
\hline$N=286$ & $162(56.6)$ & $124(43.4)$ & - \\
\hline Hypertension & $105(64.8)$ & $81(65.3)$ & 0.93 \\
\hline Coronary heart disease & $112(69.6)$ & $91(73.4)$ & 0.48 \\
\hline Previous heart infarct & $24(14.8)$ & $21(16.9)$ & 0.63 \\
\hline Heart infarct on admission & $1(0.6)$ & $3(2.4)$ & 0.20 \\
\hline First abnormal ECG & $89(54.9)$ & $85(68.6)$ & 0.02 \\
\hline Atrial fibrillation & $45(27.8)$ & $56(45.2)$ & 0.002 \\
\hline History of atrial fibrillation with anticoagulant therapy & $17(10.5)$ & $15(12.1)$ & 0.67 \\
\hline PSVT & $39(24.1)$ & $20(16.1)$ & 0.10 \\
\hline Antiplatelet therapy before stroke & $92(56.8)$ & $77(62.1)$ & 0.37 \\
\hline Anticoagulant therapy before stroke & $18(11.1)$ & $18(14.5)$ & 0.39 \\
\hline Congestive heart failure & $12(7.4)$ & $12(9.7)$ & 0.49 \\
\hline$N=233$ & $153(65.7)$ & $80(34.3)$ & \\
\hline Enlarged left atrium & $71(47.6)$ & $35(43.8)$ & 0.57 \\
\hline Enlarged left ventricle & $30(19.6)$ & $21(26.3)$ & 0.24 \\
\hline Patent foramen ovale & $3(2.0)$ & $1(1.3)$ & 0.69 \\
\hline Left ventricular wall dyskinesia & $66(43.1)$ & $39(48.8)$ & 0.53 \\
\hline Calcification and/or thickening of mitral valve & $49(32.0)$ & $25(31.3)$ & 0.90 \\
\hline Calcification and/or thickening of aortic valve & $88(57.5)$ & $46(57.5)$ & 0.99 \\
\hline Mitral stenosis & $4(2.6)$ & 0 & 0.15 \\
\hline Aortic stenosis & $11(7.2)$ & $2(2.5)$ & 0.14 \\
\hline Reduced ejection fraction $\leq 35 \%$ & $9(5.9)$ & $9(11.3)$ & 0.15 \\
\hline
\end{tabular}


gestive heart failure in $8.4 \%$ of patients, but we recognized cardiogenic stroke in $31.5 \%$ of patients.

The first abnormal ECG and the presence of AF were more frequent in patients with an unfavorable outcome than in patients with a favorable outcome. There were no differences between groups according to vascular risk factors or TTE and TEE parameters (Table 1). There were also no differences between groups of patients with and without HT according to vascular risk factors or TTE parameters. The presence of an enlarged left ventricle was more frequent in patients with a HT than in those without a HT, but the difference was not significant (Table 2).

The first abnormal ECG and the presence of AF were more frequent in patients who died within 3 months' follow-up than in those who survived (Table 3). Only median NIHSS score at the time of admission, beyond the presence of AF, and pre-stroke coagulant use, was associated with cardiogenic stroke when compared to patients with other types of strokes. Sig- nificant differences in the long-term outcome, HT and SICH rates and mortality between the subgroups of patients with cardiogenic and other types of strokes were not observed (Table 4).

Multivariate analysis showed the impact of AF on the long-term unfavorable outcome and mortality rate. Only the presence of AF was associated with cardiogenic stroke (Table 5).

\section{Discussion}

The etiology of stroke is undoubtedly multifactorial. It determines the future management of the patients. If cerebral ischemia is associated with cardiac thrombi, oral anticoagulation is the treatment of choice. Therefore, for the detection of both serious cardiac arrhythmias and subclinical disorders, changes in TTE and TEE are essential.

About $15 \%$ of strokes are attributable to documented AF [15]. Epidemiologic studies indicate that many patients with AF on screening ECGs had not previous-

Table 2. Clinical characteristics of subgroups of stroke patients with and without hemorrhagic transformation after i.v. thrombolysis

\begin{tabular}{|c|c|c|c|}
\hline Variables & $\begin{array}{c}\text { With hemorrhagic } \\
\text { transformation } \\
n(\%)\end{array}$ & $\begin{array}{c}\text { Without hemorrhagic } \\
\text { transformation } \\
n(\%)\end{array}$ & $P$-value \\
\hline$N=286$ & $45(15.7)$ & $241(84.3)$ & - \\
\hline Hypertension & $32(7.1)$ & $154(63.9)$ & 0.35 \\
\hline Coronary heart disease & $33(73.3)$ & $170(70.8)$ & 0.73 \\
\hline Previous heart infarct & $6(13.3)$ & $39(16.2)$ & 0.63 \\
\hline Heart infarct on admission & 0 & $4(1.7)$ & 0.38 \\
\hline First abnormal ECG & $31(68.9)$ & $143(59.3)$ & 0.23 \\
\hline Atrial fibrillation & $19(42.2)$ & $82(34.0)$ & 0.29 \\
\hline History of atrial fibrillation with anticoagulant therapy & $5(11.1)$ & $27(11.2)$ & 0.99 \\
\hline PSVT & $12(26.7)$ & $47(19.5)$ & 0.28 \\
\hline Antiplatelet therapy before stroke & $27(60.0)$ & $142(58.9)$ & 0.89 \\
\hline Anticoagulant therapy before stroke & $5(11.1)$ & $31(12.9)$ & 0.75 \\
\hline Heart failure & $4(8.9)$ & $20(8.3)$ & 0.87 \\
\hline$N=233$ & $29(12.5)$ & $204(87.6)$ & \\
\hline Enlarged left atrium & $14(48.3)$ & $92(45.1)$ & 0.75 \\
\hline Enlarged left ventricle & $10(34.5)$ & $41(20.1)$ & 0.08 \\
\hline Patent foramen ovale & $1(3.5)$ & $3(1.5)$ & 0.44 \\
\hline Left ventricular wall dyskinesia & $15(51.7)$ & $90(44.1)$ & 0.44 \\
\hline Calcification and/or thickening of mitral valve & $6(20.7)$ & $68(33.3)$ & 0.17 \\
\hline Calcification and/or thickening of aortic valve & $16(55.2)$ & $118(57.8)$ & 0.79 \\
\hline Mitral stenosis & 0 & $4(2.0)$ & 0.45 \\
\hline Aortic stenosis & $1(3.5)$ & $12(5.9)$ & 0.59 \\
\hline Reduced ejection fraction $\leq 35 \%$ & $3(10.3)$ & $15(7.4)$ & 0.57 \\
\hline
\end{tabular}

PSVT - paroxysmal supraventricular tachycardia, ECG - electrocardiography. 
Table 3. Clinical characteristics of subgroups of stroke patients who survived or died after i.v. thrombolysis

\begin{tabular}{|c|c|c|c|}
\hline Variables & $\begin{array}{l}\text { Dead } \\
n(\%)\end{array}$ & $\begin{array}{l}\text { Alive } \\
n(\%)\end{array}$ & $P$-value \\
\hline$N=286$ & $51(17.8)$ & $235(82.2)$ & \\
\hline Hypertension & $33(64.7)$ & $153(65.1)$ & 0.96 \\
\hline Coronary heart disease & $40(78.4)$ & $163(69.7)$ & 0.21 \\
\hline Previous heart infarct & $7(13.7)$ & $38(16.2)$ & 0.66 \\
\hline Heart infarct on admission & 0 & $4(1.7)$ & 0.35 \\
\hline First abnormal ECG & $39(76.5)$ & $135(57.5)$ & 0.02 \\
\hline Atrial fibrillation & $27(52.9)$ & $74(31.5)$ & 0.004 \\
\hline History of atrial fibrillation with anticoagulant therapy & $6(11.8)$ & $26(11.1)$ & 0.89 \\
\hline PSVT & $7(13.7)$ & $52(22.1)$ & 0.18 \\
\hline Antiplatelet therapy before stroke & $36(70.6)$ & $133(56.6)$ & 0.07 \\
\hline Anticoagulant therapy before stroke & $6(11.8)$ & $30(12.8)$ & 0.85 \\
\hline Heart failure & $3(5.9)$ & $21(8.9)$ & 0.66 \\
\hline$N=233$ & $14(6.0)$ & $219(94.0)$ & \\
\hline Enlarged left atrium & $3(21.4)$ & $104(47.5)$ & 0.06 \\
\hline Enlarged left ventricle & $2(14.3)$ & $49(22.4)$ & 0.48 \\
\hline Patent foramen ovale & $1(7.1)$ & $3(1.4)$ & 0.11 \\
\hline Left ventricular wall dyskinesia & $6(46.2)$ & $99(45.2)$ & 0.86 \\
\hline Calcification and/or thickening of mitral valve & $6(42.9)$ & $68(31.1)$ & 0.36 \\
\hline Calcification and/or thickening of aortic valve & $8(57.1)$ & $126(57.5)$ & 0.98 \\
\hline Mitral stenosis & 0 & $4(1.8)$ & 0.45 \\
\hline Aortic stenosis & 0 & $13(5.9)$ & 0.61 \\
\hline Reduced ejection fraction $\leq 35 \%$ & $1(7.1)$ & $25(11.4)$ & 0.62 \\
\hline
\end{tabular}

PSVT - paroxysmal supraventricular tachycardia, ECG - electrocardiography.

ly received a diagnosis of AF. One quarter of AIS are of unknown cause. Subclinical AF is often suspected to be the cause in patients with AIS and without an etiologic factor identified $[16,17]$. On the other hand, in $50 \%$ to $60 \%$ of patients with AF cerebral ischemic incidents were documented [15].

Approximately $1 \%$ to $2 \%$ of all adults in developed countries have CHF; its prevalence increases steeply with age [18]. Major risk factors for CHF are arterial hypertension, myocardial infarction (MI), valvular heart disease, diabetes and AF [19]. The 1-year survival rate is $55 \%$ in CHF patients associated with limitation of moderate activity (NYHA class III) and the 1-year survival rate as low as $5 \%$ to $15 \%$ in patients with symptoms occurring at rest (NYHA class IV) was found [20]. The prevalence of accompanying AF in CHF patients is $10 \%$ to $17 \%$. This is relevant, because $\mathrm{AF}$ is associated with increased stroke risk and mortality in patients with CHF [21]. The CHF is a common cause of ischemic stroke [19, 22]. The most frequently recognized reasons for cardioembolic stroke in patients with $\mathrm{CHF}$ are thrombus formation due to AF and left ventricular hypokinesia [22]. Patients with $\mathrm{CHF}$ are at risk for stroke of large-artery atherosclerosis and small-vessel occlusion [23]. In addition, hypotension in $\mathrm{CHF}$ patients is also a risk factor for stroke [24].

In the previous trials evaluating the safety and effectiveness of i.v. thrombolysis with use of alteplase, AF was found with different rates. In the NINDS study, there were $18-20 \%$ with AF [25]; in ECASS 1 - $17.5 \%$ [26], ECASS $2-21.8 \%$ [27], ECASS $3-12.7 \%$ [28] and IST-3 - 31\% [29]. In these trials, the incidence and the impact of the CHF on the long-term outcome were not studied.

In the Safe Implementation of Thrombolysis in Stroke-Monitoring Study (SITS-MOST) AF occurred in $23.2 \%$ of patients and was a predictor of symptomatic intracerebral hemorrhage (SICH) (independently from the definition), unfavorable outcome and death, and CHF occurred in $7.3 \%$ of patients and was a predictor of unfavorable outcome and death [30]. The previously published paper by Palumbo et al. revealed that clinical diagnosis of $\mathrm{CHF}$, with estimation of the left ventricu- 
Table 4. Clinical characteristics of subgroups of thrombolytic patients with cardiogenic and other subtypes of stroke

\begin{tabular}{|c|c|c|c|}
\hline Variables & $\begin{array}{c}\text { Cardiogenic strokes } \\
n(\%)\end{array}$ & $\begin{array}{l}\text { Other strokes } \\
n(\%)\end{array}$ & $P$-value \\
\hline$N(\%)$ & $90(31.5)$ & $196(68.5)$ & - \\
\hline \multicolumn{4}{|l|}{ Demographic data: } \\
\hline Age $\pm S D$, mean & $69.3(11.4)$ & $70.3(11.0)$ & 0.55 \\
\hline Male gender, $n(\%)$ & $51(56.7)$ & $104(53.1)$ & 0.57 \\
\hline Age $>80, n(\%)$ & $14(15.6)$ & $35(17.9)$ & 0.63 \\
\hline \multicolumn{4}{|l|}{ Risk factors, $n(\%)$ : } \\
\hline Hypertension & $58(64.4)$ & $128(65.3)$ & 0.89 \\
\hline Coronary heart disease & $57(63.3)$ & $104(53.1)$ & 0.10 \\
\hline Atrial fibrillation & $51(56.67)$ & $50(25.5)$ & $<0.0001$ \\
\hline Diabetes mellitus & $14(15.6)$ & $28(14.3)$ & 0.78 \\
\hline Dyslipidemia & $64(71.1)$ & $158(80.6)$ & 0.07 \\
\hline Smoking & $19(21.1)$ & $40(20.4)$ & 0.89 \\
\hline Prior stroke & $15(16.7)$ & $29(14.8)$ & 0.68 \\
\hline Pre-stroke antiplatelets & $58(64.4)$ & $111(56.6)$ & 0.21 \\
\hline Pre-stroke anticoagulants & $18(20.0)$ & $18(9.2)$ & 0.01 \\
\hline Congestive heart failure & 17 (18.9) & $7(3.6)$ & $<0.001$ \\
\hline \multicolumn{4}{|l|}{ Stroke severity: } \\
\hline Median NIHSS (IQR) & $12.0(10.0-17.0)$ & $10.0(7.0-16.0)$ & 0.01 \\
\hline NIHSS > 14 points, $n(\%)$ & $34(37.8)$ & $57(29.1)$ & 0.14 \\
\hline \multicolumn{4}{|c|}{ Radiological findings before thrombolysis in CT scans, $n(\%)$ : } \\
\hline Old ischemic changes & $32(35.6)$ & $73(37.2)$ & 0.78 \\
\hline Early ischemic changes & $20(22.2)$ & $43(21.9)$ & 0.96 \\
\hline \multicolumn{4}{|l|}{ Logistic times and factors: } \\
\hline Onset to door time (IQR) [min] & $90.0(65.0-120.0)$ & $85.0(55.0-120.0)$ & 0.30 \\
\hline Onset to door time > $60 \mathrm{~min}, n(\%)$ & $72(80.0)$ & $143(72.9)$ & 0.20 \\
\hline$\underline{\text { Door to treatment time }(\mathrm{IQR})[\mathrm{min}]}$ & $62.0(45.0-85.0)$ & $65.0(50.0-88.5)$ & 0.61 \\
\hline Onset to treatment time $(\mathrm{IQR})[\mathrm{min}]$ & $157.5(135.0-180.0)$ & $155.0(130.0-180.0)$ & 0.49 \\
\hline mRS $0-2$ at 3 months, $n(\%)$ & $45(50.0)$ & $117(59.7)$ & 0.12 \\
\hline Hemorrhagic transformation $(\mathrm{HT})^{\dagger}, n(\%)$ & $15(16.7)$ & $30(15.3)$ & 0.77 \\
\hline $\mathrm{SICH}^{\dagger}, n(\%)$ & $6(6.7)$ & $6(3.1)$ & 0.16 \\
\hline Mortality, $n(\%)$ & 17 (18.9) & 34 (17.4) & 0.75 \\
\hline
\end{tabular}

${ }^{\dagger}$ According to the ECASS 2 criteria, NIHSS - National Institutes of Health Stroke Scale, CT - computed tomography, mRS - modified Rankin Scale, ECASS - European Cooperative Acute Stroke Study, SICH - symptomatic intra-cerebral hemorrhage, SD - standard deviation, IQR interquartile range $\left(Q_{1}-Q_{3}\right)$.

lar ejection fraction, predicts mortality, but not disability, in AIS patients undergoing i.v. thrombolysis [31]. In our sample, we found $\mathrm{AF}$ in $35.5 \%$ and $\mathrm{CHF}$ in $8.4 \%$ of patients. Only AF was associated with unfavorable long-term outcome and mortality rate.

In our sample we found 2 cases of patients with AIS after percutaneous coronary intervention (PCI)
[32]. Although the overall rate of stroke after PCI is low, ranging from $0.2 \%$ to $0.4 \%[33,34]$, it is a complication associated with a high rate of morbidity and mortality [35, 36]. Dukkipati et al. found that the occurrence of stroke was more frequently associated with diabetes mellitus, hypertension, prior stroke, and renal failure and was associated with in-hospital death 
Table 5. Multivariate logistic regression analysis showing pathological changes in circulatory system associated with an unfavorable outcome, hemorrhagic transformation and death (analysis includes variables that showed discriminating power $p \leq 0.1$ in the corresponding univariate model)

\begin{tabular}{|c|c|c|c|c|c|c|}
\hline \multirow[t]{2}{*}{ Variables } & \multicolumn{2}{|c|}{ Unfavorable outcome } & \multicolumn{2}{|c|}{ Hemorrhagic transformation } & \multicolumn{2}{|l|}{ Death } \\
\hline & OR $(95 \% \mathrm{Cl})$ & $P$-value & OR $(95 \% \mathrm{Cl})$ & $P$-value & OR $(95 \% \mathrm{Cl})$ & $P$-value \\
\hline Atrial fibrillation & $1.89(1.11-3.19)$ & 0.02 & - & & $1.99(1.04-3.85)$ & 0.04 \\
\hline First abnormal ECG & $1.44(0.85-2.44)$ & 0.17 & - & & $1.88(0.89-3.96)$ & 0.10 \\
\hline PSVT & $0.47(0.15-1.45)$ & 0.19 & - & & - & \\
\hline Enlarged left ventricular & $0.53(0.18-1.57)$ & 0.25 & - & & - & \\
\hline
\end{tabular}

PSVT - paroxysmal supraventricular tachycardia, ECG - electrocardiography, OR - odds ratio, $\mathrm{Cl}$ - confidence interval (significant associations are shown in bold).

[33]. De Marco et al. reported 6 cases of periprocedural ischemic stroke complicating cardiac interventions in which immediate cerebral angiography followed by local thrombolysis was the key factor in their successful management [37]. Other authors indicate the possibility of treating such patients using alteplase [38].

Four patients with AIS and concomitant MI on admission were also treated. In half of these cases good long-term outcome was found. The MI is a frequent complication in the acute phase of stroke. On the one hand, brain and myocardial damage may be related to endogenous catecholamine release [39]. On the other hand, in MI left ventricular thrombi occur, appearing mainly in anterior MI. The factors associated with the formation of post-infarction left ventricular thrombus are: apical akinesia, aneurysm, and poor myocardial contractility, especially with an ejection fraction below 35\% [40].

A limitation of our study was the lack of echocardiography and ECG-Holter tests in all patients $(81.5 \%)$. We did not perform these examination in patients who died within the first days of hospitalization or in disturbed patients in whom Holter-ECG monitoring was difficult to perform. Echocardiography at the time of admission was impossible, because of the extension of onset to treatment times, which would be adverse to the outcome of treatment. In the group of patients without echocardiography, there were $72 \%$ of all patients who died within 90 days' follow-up.

\section{Conclusions}

It was found that AF is a strong predictor of unfavorable long-term outcome and death in patients with AIS treated with IV thrombolysis in routine practice. Echocardiographic findings which determined longterm outcome, HT and mortality rate were not found. All patients with AIS should undergo complete cardiologic diagnostic tests, including prolonged cardiac monitoring and TTE and TEE.

\section{Conflict of interest}

The authors declare no conflict of interest.

\section{References}

1. Bogousslavsky J, Melle GV, Regli F. The Lausanne Stroke Study: analysis of 1000 consecutive patients with first stroke. Stroke 1988; 19: 1083-1092.

2. Zachura M, Piątek $€$, Kurzawski J, Janion M. Coronary embolism causing acute myocardial infarction. Review of the literaturę. Medical Studies/Studia Medyczne 2016; 32: 131-135.

3. Tatschl C, Stollberger C, Matz K, Yilmaz N, Eckhardt R, Nowotny M, Dachenhausen A, Brainin M. Insular involvement is associated with QT prolongation: ECG abnormalities in patients with acute stroke. Cerebrovasc Dis 2006; 21: 47-53.

4. Tranmer BI, Keller TS, Kindt GW, Archer D. Loss of cerebral regulation during cardiac output variations in focal cerebral ischemia. J Neurosurg 1992; 77: 253-259.

5. Jauch EC, Saver JL, Adams HP, Bruno A, Connors JJ, Demaerschalk BM, Khatri P, McMullan PW Jr, Qureshi AI, Rosenfield K, Scott PA, Summers DR, Wang DZ, Wintermark M, Yonas H. American Heart Association Stroke Council; Council on Cardiovascular Nursing; Council on Peripheral Vascular Disease; Council on Clinical Cardiology. Guidelines for the Early Management of Patients With Acute Ischemic Stroke: Executive Summary. A Guideline for Healthcare Professionals From the American Heart Association/American Stroke Association. Stroke 2013; 44: 870-947.

6. Douen AG, Pageau N, Medic S. Serial electrocardiographic assessments significantly improve detection of atrial fibrillation 2.6-fold in patients with acute stroke. Stroke 2008; 39: 480-482.

7. de Bruijn SF, Agema WR, Lammers GJ, van der Wall EE, Wolterbeek R, Holman ER, Bollen EL, Bax JJ. Transesophageal echocardiography is superior to transthoracic echocardiography in management of patients of any age with transient ischemic attack or stroke. Stroke 2006; 37: 2531-2534.

8. Hacke W, Kaste M, Bluhmki E, Brozman M, Dávalos A, Guidetti D, Larrue V, Lees KR, Medeghri Z, Machnig T, Schneider D, von Kummer R, Wahlgren N, Toni D; ECASS Investigators. Thrombolysis with alteplase 3 to 4,5 hours after acute ischaemic stroke. N Engl J Med 2008; 359: 1317-1329.

9. Członkowska A, Sarzynska-Długosz I, Niewada M, Kobayashi A. Eligibility of stroke units in Poland for administration of intravenous thrombolysis. Eur J Neurol 2006; 13: $220-224$. 
10. Lyden P, Brott T, Tilley B, Welch KM, Mascha EJ, Levine S, Haley EC, Grotta J, Marler J. Improved reliability of the NIH Stroke Scale using video training. NINDS TPA Stroke Study Group. Stroke 1994; 25: 2220-2226.

11. Lang RM, Bierig M, Devereux RB, Flachskampf FA, Foster E, Pellikka PA, Pellikka PA, Picard MH, Roman MJ, Seward J, Shanewise J, Solomon S, Spencer KT, St John Sutton M, Stewart W; for the Chamber Quantification Writing Group. Recommendations for Chamber Quantification: A Report from the American Society of Echocardiography's Guidelines and Standards Committee and the Chamber Quantification Writing Group, Developed in Conjunction with the European Association of Echocardiography, a Branch of the European Society of Cardiology. J Am Soc of Echocardiogr 2005; 18: 1440-1463.

12. Adams HP, del Zoppo G, AlbertsMJ,Bhatt DL, Brass L, Furlan A, Grubb RL, Higashida RT, Jauch EC, Kidwell C, Lyden PD, Morgenstern LB, Qureshi AI, Rosenwasser RH, Scott PA, Wijdicks EFM. Guidelines for the Early Management of Adults With Ischemic Stroke. A Guidelines for the Early Management of Adults With Ischemic Stroke: A Guideline From the American Heart Association/American Stroke Association Stroke Council, Clinical Cardiology Council, Cardiovascular Radiology and Intervention Council, and the Atherosclerotic Peripheral Vascular Disease and Quality of Care Outcomes in Research Interdisciplinary Working Groups. The American Academy of Neurology affirms the value of this guideline as an educational tool for neurologists. Circulation 2007; 115: e478-e534.

13. Bonita R, Beaglehole R. Modification of Rankin Scale: recovery of motor function after stroke. Stroke 1988; 19: 1497-1500.

14. Hacke W, Kaste M, Fieschi C, von Kummer R, Davalos A, Meier D, Larrue V, Bluhmlo E, Davis S, Donnan G, Schneider D, Diez-Tejedor E, Truillas P, for the Second European-Australasian Acute Stroke Study Invastigators. Randomised double-blind placebo-controlled trial of thrombolytic therapy with intravenous alteplase in acute ischaemic stroke (ECASS II). Lancet 1998; 352: 1245-1251.

15. Wolf PA, Dawber TR, Thomas HE Jr, Kannel WB. Epidemiologic assessment of chronic atrial fibrillation and risk of stroke: the Framingham Study. Neurology 1978; 28: 973-977.

16. Tayal AH, Tian KM, Kelly M, Jones SC, Wright DG, Singh D, Jarouse J, Brillman J, Murali S, Gupta R. Atrial fibrillation detected by mobile cardiac outpatient telemetry in cryptogenic TIA or stroke. Neurology 2008; 71: 1696-1701.

17. Haelay JS, Connolly SJ, Gold MR, Israel CW, Van Gelder IC, Capucci A, Lau CP, Fain E, Yang S, Bailleul C, Morillo CA, Carlson M, Themeles E, Kaufman ES, Hohnloser $\mathrm{SH}$; the ASSERT Invastigators. Subclinical atrial fibrillation and the risk of stroke. N Engl J Med 2012; 366: 120-129.

18. Häusler KG, Laufs U, Endress M. Chronic heart failure and ischemic stroke. Stroke 2011; 42: 2977-2982.

19. Lloyd-Jones D. Heart disease and stroke statistics-2010 update. Circulation 2010; 121: e46-e215.

20. Askoxylakis V, Thieke C, Pleger ST, Most P, Tanner J, Lindel K, Katus HA, Debus J, Bischof M. Long-term survival of cancer patients compared to heart failure and stroke. BMC Cancer 2010; 10: 105.
21. Mamas MA, Caldwell JC, Chacko S, Garratt CJ, Fath-Ordoubadi F, Neyses L. A meta-analysis of the prognostic significance of atrial fibrillation in chronic heart failure. Eur J Heart Fail 2009; 11: 676-683.

22. Häusler KG, Laufs U, Endres M. Neurological aspects of chronic heart failure. Nervenarzt 2011; 82: 733-742.

23. Pullicino P, Mifsud V, Wong E, Graham S, Ali I, Smajlovic D. Hypoperfusion-related cerebral ischemia and cardiac left ventricular systolic dysfunction. J Stroke Cerebrovasc Dis 2001; 10: 178-182.

24. Pullicino PM, McClure LA, Wadley VG, Ahmed A, Howard VJ, Howard G, Safford MM. Blood pressure and stroke in heart failure in the Reasons for Geographic And Racial Differences in Stroke (REGARDS) study. Stroke 2009; 40: 3706-3710.

25. The National Institute of Neurological Diserders and Stroke rt-PA Stroke Study Group. Tissue plasminogen activator for acute ischemic stroke. N Engl J Med 1995; 333: 1581-1587.

26. Hacke W, Kaste M, Fieschi C, Toni D, Lesaffre E, von Kummer R, Boysen G, Bluhmki E, Höxter G, Mahagne MH. Intravenous thrombolysis with recombinant tissue plasminogen activator for acute hemispheric stroke. The European Cooperative Acute Stroke Study (ECASS). JAMA 1995; 274: 1017-1025.

27. Hacke W, Kaste M, Fieschi C, von Kummer R, Davalos A, Meier D, Larrue V, Bluhmki E, Davis S, Donnan G, Schneider D, Diez-Tejedor E, Trouillas P. Randomised doubleblind placebo-controlled trial of thrombolytic therapy with intravenous alteplase in acute ischaemic stroke (ECASS II). Lancet 1998; 352: 1245-1251.

28. Hacke W, Kaste M, Bluhmki E, Brozman M, Dávalos A, Guidetti D, Larrue V, Lees KR, Medeghri Z, Machnig T, Schneider D, von Kummer R, Wahlgren N, Toni D. Thrombolysis with alteplase 3 to 4.5 hours after acute ischaemic stroke. N Engl J Med 2008; 359: 1317-1329.

29. The benefits and harms of intravenous thrombolysis with recombinant tissue plasminogen activator within $6 \mathrm{~h}$ of acute ischaemic stroke (the third international stroke trial [IST-3]): a randomised controlled trial. The IST-3 collaborative group. Lancet 2012; 379: 2352-2363.

30. Wahlgren N, Ahmed N, Erikksson N, Aichner F, Bluhmki E, Dávalos A, Erilä T, Ford GA, Grond M, Hacke W, Hennerici MG, Kaste M, Köhrmann M, Larrue V, Lees KR, Machnig T, Roine RO, Toni D, Vanhooren G. Multivariable analysis of outcome predictors and adjustment of main outcome results to baseline data profile in randomized controlled trials: Safe Implementation of Thrombolysis in Stroke-Monitoring Study (SITS-MOST). Stroke 2008; 39: 3316-3322.

31. Palumbo V, Baldasseroni S, Nencini P, Pracucci G, Arba F, Piccardi B, Marella GA, Di Bari M, Gensini GF, Marchionni N, Inzitari D. The coexistence of heart failure predicts short term mortality, but not disability, in patients with acute ischemic stroke treated with thrombolysis: the Florence area Registry. Eur J Intern Med 2012; 23: 552-557.

32. Sobolewski P, Szczuchniak W, Wach-Klink A, Grzesik M. Ischemic stroke and coexisting myocardial infarction diagnosed at the time of admission - a serious therapeutic problem. Exp Clin Cardiol 2014; 20: 2849-2854.

33. Dukkipati S, O’Neill WW, Harjai KJ, Sanders WP, Deo D, Boura JA, Bartholomew BA, Yerkey MW, Sadeghi HM, Kahn JK. Characteristics of cerebrovascular accidents 
after percutaneous coronary interventions. J Am Coll Cardiol 2004; 43: 1161-1167.

34. Wong SC, Minutello R, Hong MK. Neurological complications following percutaneous coronary interventions: a report from the 2000-2001 New York State Angioplasty Registry. Am J Cardiol 2005; 96: 1248-1250.

35. Budaj A, Flasinska K, Gore JM, Anderson FA, Dabbous OH, Spencer FA, Golberg RK, Fox KA. Magnitude of and risk factors for in-hospital and post discharge stroke in patients with acute coronary syndromes: findings from a Global Registry of Acute Coronary Events. Circulation 2005; 111: 3242-3247.

36. Westerhout CM, Hernandez AV, Steyerberg EW, Bueno $\mathrm{H}$, White $\mathrm{H}$, Théroux P, Moliterno DJ, Armstrong PW, Califf RM, Wallentin LC, Simoons ML, Boersma E. Predictors of stroke within 30 days in patients with non-ST-segment elevation acute coronary syndromes. Eur Heart J 2006; 27: 2956-2961.

37. De Marco F, Antonio Fernandez-Diaz J, Lefèvre T, Balcells J, Araya M, Routledge H, Rosas A, Louvard Y, Dumas P, Morice MC. Management of cerebrovascular accidents during cardiac catheterization: immediate cerebral angiography versus early neuroimaging strategy. Catheter Cardiovasc Interv 2007; 70: 560-568.

38. Hamon M, Baron JC, Viader F, Hamon M. Periprocedural stroke and cardiac catheterization. Circulation 2008; 118 : 678-683.

39. Novitzki D, Wicomb WN, Cooper DK, Rose AG, Reichart B. Prevention of myocardial injury during brain death by total cardiac sympathectomy in the Chacma baboon. Ann Thorac Surg 1986; 41: 520-524.

40. Keren A, Golberg S, Gottlieb S, Klein J, Schuger C, Medina A, Tzivoni D, Stern S. Natural history of left ventricular thrombi: their appearance and resolution in the posthospitalization period of acute myocardial infarction. J Am Coll Cardiol 1990; 15: 790-800.

\section{Address for correspondence:}

\section{Aleksandra Wach-Klink}

Department of Neurology and Stroke Unit

Holy Spirit Specialist Hospital

ul. Schinzla 13, 27-600 Sandomierz, Poland

Phone: +48 506637107

E-mail: aleksandrawach4@gmail.com 